\title{
大阪大学情報科学研究科におけるソフトウェアデザイン 工学高度人材育成への取り組み
}

An Advanced Educational Program for Software Design Engineering at Graduate School of Information Science and Technology of Osaka University

$\begin{array}{lll}\text { 増 澤 利 光*1 } & \text { 井 上 克 郎*1 } & \text { 村 上 孝 三*1 } \\ \text { Toshimitsu MASUZAWA } & \text { Katsuro INOUE } & \text { Koso MURAKAMI }\end{array}$

$\begin{array}{ll}\text { 藤 原 } \quad \text { 融*1 } & \text { 西 尾 章治郎 } * 1 \\ \text { Toru FUJIWARA } & \text { Shojiro NISHIO }\end{array}$

This paper gives an overview of an advanced educational program for software design engineering that is currently conducted at Graduate School of Information Science and Technology, Osaka University under the grant "Initiatives for Attractive Education in Graduate Schools" from MEXT. Software design engineering is highly expected to play a critical role in winning success in designing the next-generation software systems. The aim of the program is to bring up young researchers with the latest design methodologies and practical design experience, who can pioneer the frontier of software design engineering. The program is conducted with the collaboration of industries that have rich practical experience and are facing the engineering problems to be solved in developing the next-generation software.

Keywords : Software Design Engineering, Industry-academia Collaboration, Educational Program, Initiatives for Attractive Education in Graduate Schools

キーワード：ソフトウェアデザイン工学, 産学連携, 教育プログラム, 「魅力ある大学院教育」イ ニシアティブ

\section{1.はじめに}

本稿では，文部科学省の「魅力ある大学院教育」イ ニシアティブの教育プログラムとして, 大阪大学大学 院情報科学研究科が取り組んでいる「ソフトウェアデ ザイン工学高度人材育成コア」の概要について紹介す る.

大学院情報科学研究科は, 学内に分散していた情報 科学技術に関連する教育研究組織を改組・再編し，平 成 14 年 4 月に創設された。設置の重要な目的は，「情 報科学技術」に関する先進的で専門性の高い教育研究 をより一層発展させ, 真の意味で充実した高度情報化 社会への道を拓く新技術や新研究領域の創成と, 高度 に発達した情報技術社会を支える人材の養成である. 本研究科は図 1 に示すように 7 専攻で構成され, 情報 およびネットワーク技術に関わるハードウェア，ソフ トウェア，さらにはコンテンツそのものまでを含む多 様な情報メディアを対象に, 数学的な基礎理論から先 端的な応用技術に至るまで，さらには，バイオ情報工

平成 18 年 2 月 10 日受付

※ 1 大阪大学大学院情報科学研究科

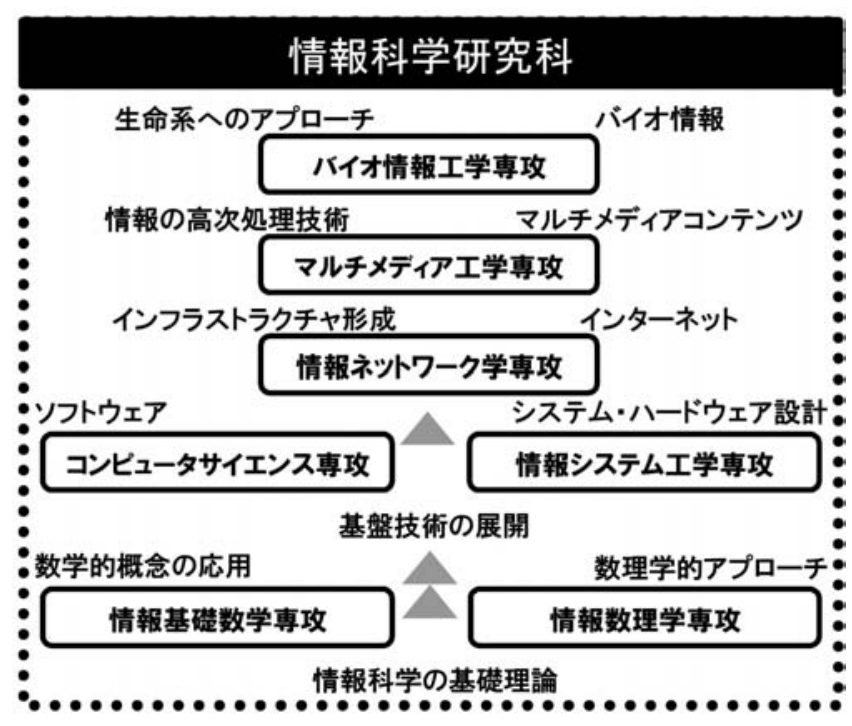

図 1 大学院情報科学研究科の専攻構成

学などの先端的で学際的領域を含む情報科学関連の広 汎な分野での教育研究に取り組んでいる。 また，本研 究科を主体とする研究教育プロジェクトが平成 14 年 度文部科学省 21 世紀 COE プログラムに採択され， 「ネットワーク共生環境を築く情報技術の創出」とい 
うテーマの下で, 7 専攻が有機的に連携しながら, 新 たな領域を拓くための教育研究活動を精力的に行って いる.

情報およびネットワークに関する技術の近年の進歩 には目をみはるものがある。しかし，我が国では，高 度な情報通信技術を駆使して, 新しいソフトウェアを 開発できる高度な情報技術者が近い将来大量に不足す ると経済界が危機感を募らせている，日本経済団体連 合会が平成 17 年 6 月に提示した提言では, この問題 に対処するために，産学官の連携を強めて高度情報通 信分野の人材育成を急ぐことの必要性が訴えられてい る ${ }^{1}$ 。本研究科では, 高度な情報通信技術者を育成す るためのさまざまな取り組みを行っているが，文部科 学省の「魅力ある大学院教育」イニシアティブの支援 を受けた本プログラムでは，これらを統合・発展させ ることにより，「ソフトウェアデザイン工学」にかか わる高度な情報通信人材の育成に取り組む．ソフトウ エアデザイン工学は，人類が 21 世紀に遭遇する諸課 題を解決するための重要な基盤技術であり，また， 「知的もの造り」の強力なッールともなり得る。なお, 経団連の提言を受けて, 本研究科の高度な情報通信人 材の育成に関する取り組みについては, 研究科レポー ト2)としてまとめている.

\section{2. 本研究科のこれまでの高度人材育成教育}

深化・拡張の極めて著しい情報およびネットワーク 関連分野における高度な研究開発活動に必要な, 情報 科学の広範にわたる最先端の知識を習得するために, 本研究科では, 専攻共通の科目を設けたり, あるいは, 他専攻の科目を専攻境界科目として学生に履修を推奨 するなど， 7 専攻が綿密に連携したカリキュラムを提 供している. 特に, 各専攻では専攻の独自色を活かし つつ，教育に関して以下の取組を実施している.

・ソフトウェア, 応用システムの実践的な開発技術を 習得することを目的とした演習科目を実施してい る.

・産業界のニーズや技術動向を知ることを目的とし， 産業界の専門家による特別講義を実施している.

・産業界の実プロジェクトへの参加経験を積むための インターンシップを授業科目として実施している.

また,「魅力ある大学院教育」イニシアテイブを中 心となって推進するコンピュータサイエンス専攻, 情 報ネットワーク学専攻, マルチメデイア工学専攻の 3 専攻では, 文部科学省「 21 世紀 COE プログラム」の 教育プログラムの一環として, 本研究科の情報技術お よびバイオ技術に関する産学連携を推進している, IT連携フォーラム OACIS の活動等を通じて, ソフト ウェア工学, ネットワーク設計, 情報セキュリテイ等 に関する高度人材育成の教育プログラムを積極的に実 施している。本COEプログラムでは，世界をリード

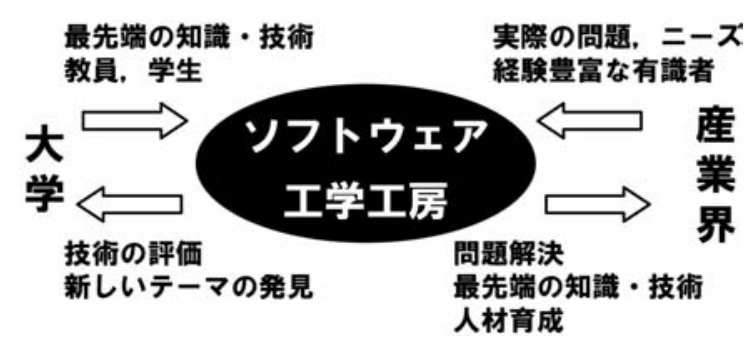

図 2 ソフトウェア工学工房

する卓越した研究拠点の形成を第一義としているが, 情報技術の創出に関連した教育プログラムを研究開発 と同時に実施することが真の拠点形成につながるとい う考えから, 教育プログラムにも重点を置いている. 以下では，その教育プログラムの概要を紹介する。

(1) ソフトウェア工学工房

ソフトゥェア工学工房 ${ }^{3)}$ は, 臨床を通じて得た現場 での知識を新たな研究テーマの発見, 展開に効果的に 連携させている「大学病院のスキーム」を, 実践的ソ フトウェア工学の教育研究に持ち込むことを意図した ものであり,ソフトウェア技術の実践教育の場として, コンピュータサイエンス専攻の井上研究室, 楠本研究 室が平成 14 年度から実施している。ここでは, 大学 からは研究者や学生が, 企業等からは研究員らが参加 し，対等な関係で実践的な問題や研究テーマについて 問題解決を図り，実践的なソフトウェア工学の技術を 身に付けることを目的としている．具体的な活動とし て，以下のことを実施している(図 2).

・最先端のソフトウェア工学技術を紹介し, 様々なツ ールを試用するソフトウェア工学セミナーを, 社会 人を対象に実施している.

・産業界の研究員による, 実践的なソフトウェア工学 技術やソフトウエア開発プロジェクトの事例紹介 を, 大学院生を対象に行っている.

・社会人ドクターを受け入れ，ソフトウェア開発現場 に扔けるプロジェクト管理支援に関する研究，再利 用技術を用いたソフトウェア品質・生産性向上に関 する研究を行っている.

これらの活動を通じて,ソフトウェア工学工房では, 高度なソフトウェア技術やコンテンツ技術を持った社 会人や学生の教育, ならびに, 社会的ニーズが高くし かも学術的な価值が高い研究テーマの発見・育成に成 果を収めている. 特に, 当該研究室で開発したコード クローン検出技術の, 産業界に打ける実際のソフトウ エア保守作業の問題解決への適用に成功するなど, 産 業界からも高く評価されている.

(2) ネットワークプロセッサ設計ラボ計画

急速に発展するネットワーク環境を支える通信制御 技術に関する先進的な教育を行うために，種々の新し い技術に対応可能な最先端システムを用いた演習を, 情報ネットワーク学専攻では平成 14 年度から行って 
いる．具体的には，ネットワーク機器用に設計された プログラマブルなプロセッサ（ネットワークプロセッ サ）を用いて, 高機能, 高性能なネットワーク制御メ カニズムの検討, 実装, 実験を行い, それらを通じて ネットワークシステムの設計, 開発能力を身に付ける ことを目的としている。新しい高度・高機能・高速ネ ットワークのシステム設計, ネットワークアプリケー ション開発にかかわる実践的演習教育を行っている.

現在，ネットワークプロセッサとしてはインテル製 のIXP1200を使用しているが, これは複数の企業にお いて実際に製品開発に供されているものであり，これ を核とした製品が市場に出されている。従って, 本プ ログラムで身に付けた技術はそのまま実社会に通用す るものである.

なお，本教育プログラムはインテル社のIXA University Program ${ }^{4)}$ にも参画しているが，国内での参 画している大学は本学と筑波大学のみである.

(3) セキュアネットワーク構築のための人材育成プ ログラム

社会の隅々まで行き渡ったネットワークは, 社会の 利便性を飛躍的に高めたが, ネットワーク社会では情 報漏えいやネットワーク犯罪など, 新たな問題が生じ ている，今後，健全なネットワーク社会として成熟し ていくためには, 安全にネットワークを利用できる環 境の実現が必要である。本教育プログラムは，七キュ リティに関する研究に加えて，それらの知識と実践的 な技術を身に付けたエキスパートを育成することを目 的として, マルチメディア工学専攻がサイバーメディ アセンターと協力して実施している.

現在, 情報通信社会の高度化・複雑化が進む中で, ネットワークセキュリティの技術者がますます不足し ている，本プログラムでは，最先端の技術を反映した 実践中心のカリキュラムと専門的な知識を十分に備え たスタッフをそろえ, 大学院生, 社会人を中心にネッ トワークセキュリティ専門技術者の育成を行ってお り, 他大学, 産業界からも高く評価されている. なお, 本プログラムは平成 13 年度より, 文部科学省科学技 術振興調整費（振興分野人材育成）の助成を受けて実 施されているが, 平成 14 年度からはCOEプログラム の一部としての性格も持っている.

\section{3. ソフトウェアデザイン工学高度人材育成コア}

平成 17 年度から 2 年間, 文部科学省の「魅力ある 大学院教育」イニシアティブの助成を得て,「ソフト ウェアデザイン工学高度人材育成コア」プログラムを, コンピュータサイエンス専攻, 情報ネットワーク学専 攻, マルチメディア工学専攻が中心となって, 情報科 学研究科全体で推進している。平成 17 年度は実質的 には11月からの開始のため, 現在, まだ準備・試行 段階であり，本格的な実施は平成 18 年度からとなっ
ている. 本プログラムは, ソフトウェアデザイン工学 の実践的な教育を実施するために，前述のこれまでの 実践的教育をべースに，さらなる発展・拡充を目指す ものである。

\section{1 本プログラムの目的}

本プログラムは, 次世代の先端情報システムの研究 開発を世界的にリードし, 特に, 次世代の高度ソフト ウェアシステムの核となる革新的技術の創出, 高度運 用, 新たな応用分野の開拓に携わることのできる人材 の育成を目指している. 具体的には, 先端情報システ ムの開発に扔ける, 要求分析, モデル化, システム構 築の全過程で求められる能力, さらにはプロジェクト マネジメント能力というような, 総合的なソフトウェ アデザインカを有する, ソフトウェアデザイン工学に おける世界トップランクの人材育成を目指している.

今日の先端情報システムでは, ネットワークは不可 欠な構成要素であり, また, マルチメディアの取り扱 いも不可欠である. そこで, 従来のソフトウェアに加 え, ネットワークソフトウェア, 拈よびマルチメディ アソフトウェアを対象に, ソフトウェアデザインカを 有する人材の育成を目指す.

\section{2 本プログラムの実施方法}

本プログラムの目的を達成するために，本プログラ ムでは, カリキュラムの拡充, ソフトウェア工学工房 の拡張, 産業界との連携の強化, 国際性豊かな人材の 育成を実施する（図 3 ）。

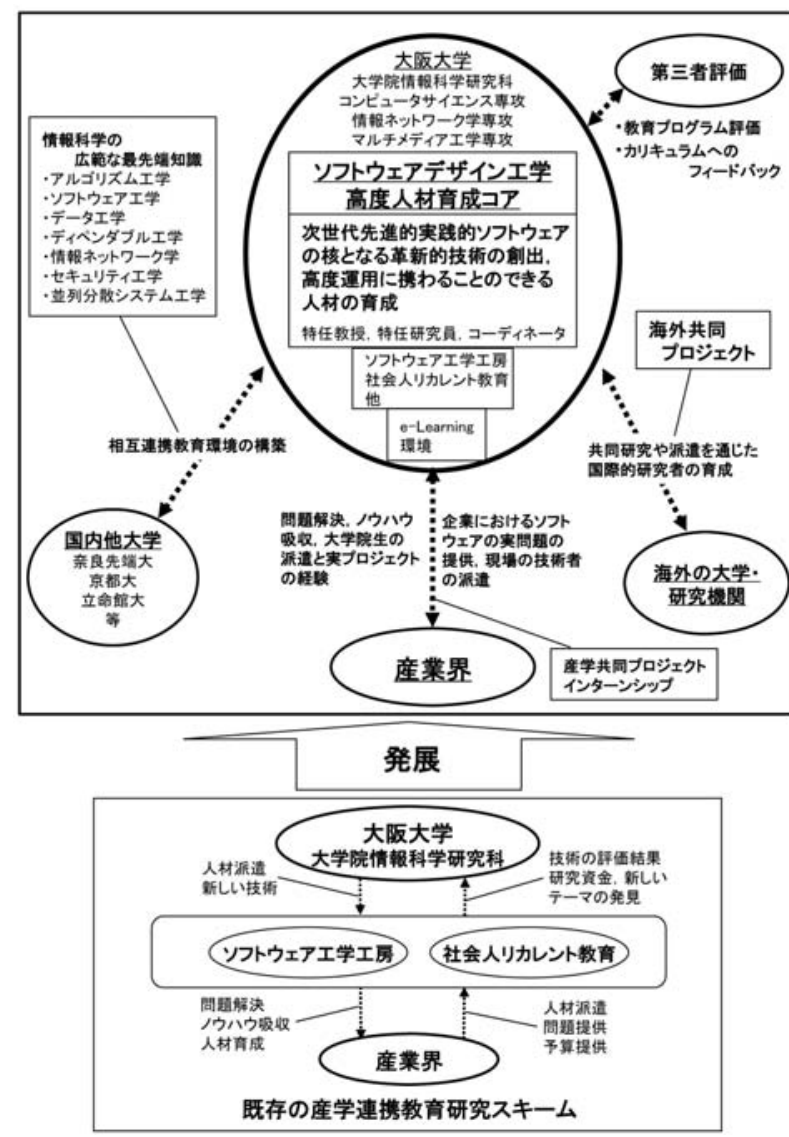

図 3 履修プロセスの概念図 
(1) カリキュラムの拡充

最先端の情報およびネットワーク関連の教育, 特に ソフトウェア工学, ネットワークソフトウェア, マル チメディアソフトウェア，プロジェクトマネジメント に関する授業科目を充実し，産業界で利用されている 最先端の知識や技術を修得し, 数多くのケーススタデ イについて学ぶ。演習科目では, 課題プロジェクトを 設定することにより，これらの最先端の知識や技術を 適用すると同時に, プロジェクトマネージメントにつ いて学ぶ。演習科目ではこれまでも実践的な課題に取 り組んできているが，これらの教育をより発展させる ために, 本プログラムでは, 産学連携の共同研究や IT 連携フォーラム OACIS, ソフトウェア工学工房, 経団連の提言などを通じて得た産業界の教育ニーズを より反映した課題を設定していく．さらにインターン シップ科目では，これらの知識を背景に，より現実の 問題を解くことにより, 知識の実働化を目指す. 特に, 産業界の実プロジェクトに参加し, 自主的な問題発見, 問題解決を経験することにより, 問題発見能力, 問題 解決能力, 創造力の向上を図っている. 本プログラム 履修者には, これらの講義科目, 演習科目, インター ンシップ科目を必修とすることによって，単なる知識 の習得のみならずその実働化に努める。本プログラム で規定した授業の履修者には，「ソフトウェアデザイ ン工学高度人材育成プログラム」の修了証を発行し, 学生へのインセンティブとする.さらにこれらの活動 を広く産業界に知らせ，本プログラムの評価向上に努 めるとともに, 社会人学生の増加を図る.

具体的には，例えば，コンピュータサイエンス専攻 では, 実践的なソフトウェア工学の最先端の知識や技 術を学び，それらの知識や技術を実プロジェクトに適 用し, 同時にプロジェクトマネジメントについても学 ベるようにカリキュラムの整備を行った，そのために， ソフトウェア工学に関する講義 2 科目, 演習科目 2 科 目の全面的な改訂を行った。これにより, 講義 2 科目, 演習 2 科目の講義時間である, 90 分の講義 60 回の効 果的な連携が可能となり, 実践的ソフトウェア工学の 修得を可能にした。コンピュータサイエンス専攻にお ける実践的ソフトウェア工学に関わる, 平成 18 年度 の講義, 演習科目の内容を表 1 にまとめておく.

また, 京都大学, 奈良先端科学技術大学院大学, 立 命館大学など, 実践ソフトウェアの教育研究に成果を あげている関西の他大学と大学間連携を進め, それぞ れの得意分野を活用した相互連携教育研究環境を整備 し, 情報科学の広汎な最先端の知識を学ぶ環境をさら に拡充する計画である。

(2) ソフトウェア工学工房の拡張

ソフトウェア工学工房では, 前述したように, 大学 からの研究者や学生と企業等からの研究員が, 対等な 関係で実践的な問題や研究テーマについて問題解決を
表 1 実践的ソフトウェア工学カリキュラム

\begin{tabular}{|c|c|c|}
\hline & 情報システムと社会 & $\begin{array}{l}\text { 情報化社会の意味, 情報技術の } \\
\text { 応用分野, 開発事例 }\end{array}$ \\
\hline \multirow{4}{*}{$\begin{array}{l}\text { 技 } \\
\text { 術 } \\
\text { キ } \\
\text { ル }\end{array}$} & 要求定義 & $\begin{array}{l}\text { RFPからシステム提案, システ } \\
\text { ム計画 }\end{array}$ \\
\hline & $\begin{array}{l}\text { データ/ビジネス } \\
\text { モデリング }\end{array}$ & $\begin{array}{l}\text { データ分析とE-Rモデリング, } \\
\text { UMLによるビジネスモデリング }\end{array}$ \\
\hline & $\begin{array}{l}\text { 開発技術／ } \\
\text { テスト技術 }\end{array}$ & $\begin{array}{l}\text { オープン環境でのシステム開 } \\
\text { 発, テストケース作成と実行 }\end{array}$ \\
\hline & 運用・保守技術 & アウトソーシング（SLA, ITIL) \\
\hline \multirow{5}{*}{ 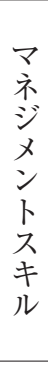 } & 見積技術 & $\begin{array}{l}\text { ソフトウェア規模見積の流れ, } \\
\text { FP法による見積 }\end{array}$ \\
\hline & プロセス管理 & ソフトウェア開発の流（SLCP） \\
\hline & プロジェクト管理 & $\begin{array}{l}\text { プロジェクト管理のしくみ, } \\
\text { データの収集と分析, 可視化, } \\
\text { SI企業のプロジェクト管理制度 }\end{array}$ \\
\hline & 検査と品質保証 & ソフトウェアの品質保証 \\
\hline & システム監査 & 企業内部統制（Sox法など） \\
\hline \multirow{3}{*}{ 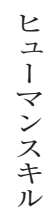 } & 情報と職業 & $\begin{array}{l}\text { IT技術者の要件とスキル（ITSS）, } \\
\text { CDP(Career Development Program) }\end{array}$ \\
\hline & 思考技術 & 問題把握・分析 · 重点化スキル \\
\hline & $\begin{array}{l}\text { 守るべき法律と倫理 } \\
\text { (コンプライアンス) }\end{array}$ & 個人情報保護法, 知的財産法など \\
\hline
\end{tabular}

四ることにより，実践的ソフトウェア工学の技術を身 に付けるための実践教育の場の提供に成功を収めてい る.

「魅力ある大学院教育」イニシアティブの本プログ ラムでも, 豊富な知識と経験を有する産業界の人材を 積極的に活用する。具体的には，産業界における実プ ロジェクトでの実践的なソフトウェア工学, ネットワ ークソフトウェア，マルチメディアソフトウェアの技 術について学ぶために, 講義科目や演習科目に産業界 の研究開発者を講師として任用し, 産業界で活用され ている実践的な知識や技術を学ぶとともに, 数多くの ケーススタデイについて学ぶ. 産業界の人材について は, 講義科目や演習科目の講師に任用するだけでなく, 産業界のニーズに応えるために, 講義内容や演習内容 の策定を含めた，本プログラムのデザインから産業界 の有識者に参画いただいている.

(3) 産業界との連携の強化

本研究科ではこれまでにも, インターンシップ, 産 学連携の共同研究やIT連携フォーラム OACIS, ソフ トゥェア工学工房, 社会人リカレント教育などを通じ て, 産業界との連携を強力に推進している. 特に, イ ンターンシップについては, 平成 17 年度よりインタ ーンシップ科目として単位化することにより，履修を 学生に強く推奨している.

「魅力ある大学院教育」イニシアティブの本プログ ラムでは, インターンシップを原則として必修とし, 産業界で活用されている最先端の知識や技術を修得し た本プログラム修了者の育成を目指す。これにより， 
産業界が必要としている, 即戦力となりうる修了者の 育成を目指す。

また，ソフトウェア工学工房の項目でも述べたよう に，本プログラムのカリキュラムの策定段階から産業 界の有識者の意見を採り入れることにより, 従来の実 践的教育に比べ，より綿密な産学連携による教育モデ ルの確立を目指す。

(4) 国際性豊かな人材の育成

次世代の先端情報システムの研究開発を世界的にリ 一ドしうる人材は，最先端の知識や技術に通じ，それ らの実践的な実働化ができるだけでなく，豊かな国際 性を備えることも必要である.

本研究科では, 文部科学省の「大学教育の国際化推 進プログラム（戦略的国際連携支援）」に，平成 17 年 度からの 4 年間のプログラムとして,「融合科学を国 際的視野で先導する人材の育成」プログラムが採択さ れ，米国カリフォルニア大学サンディエゴ校などと連 携した国際的人材育成ネットワークが構築されつつあ る. 授業科目として「海外インターンシップ」が設置 されるなど, 国際性豊かな人材を育成する環境が整い つつある。

「魅力ある大学院教育」イニシアティブの本プログ ラムでも，この国際化推進プログラムと連携すること により, 海外インターンシップによる, 海外プロジェ クトへの参加や, 海外からの研究者の招聘などを通じ て, 国際性豊かな人材の育成を推進し, ソフトウェア デザイン工学における, 世界トップクラスの人材育成 に努める.

なお, 産学連携プロジェクト（前項）のためのイン ターンシップや, 海外プロジェクトのための海外イン ターンシップのために, 学外での教育研究活動に従事 する学生が, 自学自習による講義履修を可能にするた めに, e-Learning 環境の構築, および e-Learning 教材 の整備を，本プログラムのもとで実施していく.

\section{4.まとめ}

本稿では, 文部科学省の「鬼力ある大学院教育」イ ニシアティブの教育プログラムとして, 大阪大学大学 院情報科学研究科が取り組んでいる「ソフトウェアデ ザイン工学高度人材育成コア」の概要について紹介し た.

本プログラムは, 次世代の先端情報システムの研究 開発を世界的にリードし, 特に, 次世代の高度ソフト ウェアシステムの核となる革新的技術の創出, 高度運 用，新たな応用分野の開拓に携わることのできる人材
の育成を目指している。具体的には, 先端情報システ ムの開発における, 要求分析, モデル化, システム構 築の全過程で求められる能力, さらにはプロジェクト マネジメント能力というような, 総合的なソフトウェ アデザイン力を有する, ソフトウェアデザイン工学に おける世界トップランクの人材育成を目指している.

本教育プログラムは主に博士前期課程学生を対象と しているが, 本プログラム修了者が後期課程へ進学し, 研究者となることが期待される。 これによって, 実プ ロジェクトでの問題解決に実働できる情報科学の最先 端の知識を有し, 産業界の実際のニーズを知り, 産業 界で実際に用いられている技術を体得し，また，ソフ トウェアシステムの実際の研究開発プロジェクトのマ ネジメント法を身につけている研究者の育成が可能に なる。これらの研究者を通じて, 産学連携研究をより 強力に推進することが可能になり, その産学連携研究 から次世代の高度ソフトウェアシステムの核となる革 新的技術が創出されることを期待している.

\section{参 考 文 献}

1）（社）日本経済団体連合会：産学官連携による高 度な情報通信人材の育成強化に向けて, http:// ww w.keidanren.or.jp/japanese/policy/ 2005/039/index.html

2) 大阪大学大学院情報科学研究科：大阪大学におけ る高度な情報通信人材の育成に関する取り組み, http://www.ist.osaka-u.ac.jp/japanese/pdf/ ICT- IST-Finall.pdf

3 ）ソフトウェア工学工房, http://iip-lab.ics.es. osaka-u.ac.jp/ kobo/index.html.ja

4 ) Intel: IXA University Program, http://www. ixaedu.com/home

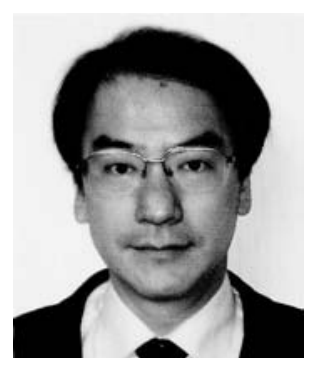

著者紹介

増澤 利光

昭 57 阪大 · 基礎工 · 情報卒. 昭 62 同大大学 院博士後期課程了. 同年同大情報処理教育 センター助手. 同大基礎工助教授を経て, 平 6 奈良先端科学技術大学院大学情報科学 研究科助教授. 平 12 阪大基礎工学研究科教 授, 平14 阪大情報科学研究科コンピュー夕 サイエンス専攻教授, 現在に至る。平 5 コ 一ネル大客員準教授（文部省在外研究員）. 分散アルゴリズム, 並列アルゴリズムに関 する研究に従事. 工博. ACM, IEEE, 電 子情報通信学会, 情報処理学会各会員. 